\title{
O ROMANCE A HISTÓRIA DO AMOR DE FERNANDO E ISAURA EM RELAÇÕES DIALÓGICAS: DO MEDIEVO AO NORDESTE
}

\author{
Janielly Santos de V asconcelos Viana* \\ Ramisio Vieira de Souza $a^{* *}$ \\ Maria de Fátima Almeida ${ }^{* * *}$
}

RESUMO: Esta pesquisa tematiza o percurso dialógico que constitui a formação do romance $A$ bistória do amor de Fernando e Isaura (1994), de Ariano Suassuna, com base em Bakhtin (2014) para quem o romance é uma diversidade social de linguagens organizadas artisticamente, por línguas e vozes individuais. O estudo das relações dialógicas é condição indispensável para compreensão dos sentidos que determinam a discursividade de um gênero, em perspectiva dialógica. Em vista disso, investigamse as relações que organizam e constituem o romance de Fernando e Isaura, de modo que o objetivo desta pesquisa é compreender como as relações dialógicas contribuem para formação e compreensão dos sentidos em um romance. Em função do objeto de estudo, desenvolve-se uma pesquisa de método descritivo-interpretativista de abordagem qualitativa, contudo, as análises tomam por base teórico-metodológica, a Teoria Dialógica da Linguagem. Os pressupostos teóricos constituem-se da revisão literária das obras de Bakhtin (2011, 2014 e 2015) E Bakhtin/Volochínov (1981). Compreendese que o romance pode mesclar, misturar e pluralizar vozes e, que o caráter dialógico que o constitui, coloca suas linguagens frente a frente ao contexto social e real da linguagem, através da interação dos espaços e discursos. O romance prosaico de Fernando Isaura é sinônimo de renovação de sentidos, uma vez que representa a atividade de escrita suassuniana e procura resgatar elementos da cultura erudita nos romances Tristan et Iseut (1903), de Béroul e Tristão e Iseu (1976), de Joseph Bédier (versão traduzida de Afrânio Peixoto), exaltando o imaginário nordestino popular.

PALAVRAS-CHAVE: Relações dialógicas; Romance; Ariano Suassuna; Cultura Popular.

\section{Introdução}

As reflexões propostas por Bakhtin e o Círculo, atualmente, tornaram-se objeto de discussões, ao tempo em que servem de base teórica para o desenvolvimento de investigações em diversos campos do conhecimento. Mikhail Bakhtin (1895-1975) foi inicialmente reconhecido como teórico e estudioso literário. Para consolidar-se no debate estético e

\footnotetext{
* Doutoranda e mestre em Linguística pela Universidade Federal da Paraíba (UFPB). Participa como pesquisadora integrante do Grupo de Estudos em Linguagem, Enunciação e Interação (GPLEI).

${ }^{* *}$ Doutorando e mestre em Linguística pela Universidade Federal da Paraíba (UFPB).

*** Doutora em Linguística pela Universidade Federal de Pernambuco (UFPE). Professora associada do Departamento de Letras Clássicas e Vernáculas da Programa de Linguística (PROLING) da Universidade Federal da Paraíba (UFPB).
} 
literário que, em seu tempo, estabelecia-se, Bakhtin se diferenciava dos pensamentos predominantemente formalistas, colocando à prova as afirmações que esgotavam a obra literária à materialidade do texto. Os estudos linguísticos, de Bakhtin, voltaram-se para os estudos literários e ampliaram compreensões sobre a obra literária, destacando a função da linguagem que, assim como a palavra, "está sempre carregada de um conteúdo ou de um sentido ideológico ou vivencial” (BAKHTIN, 1981, p. 95), assim, permitindo, ao homem elaborar sua visão de mundo, sua compreensão de si e dos outros.

Ao destacar a língua como papel central na formação social do indivíduo, Bakhtin ressalta o caráter constitutivamente dialógico da linguagem. Em várias obras resultantes de seus estudos, especificamente em Problemas da poética de Dostoievski, publicado primeiramente em 1929, Bakhtin (2015) assegura que a linguagem está impregnada e carregada de relações dialógicas. Nesta perspectiva, esta pesquisa deriva-se das nossas leituras orientadas pela Teoria dialógica da linguagem, sobre os gêneros discursivos, dentre os quais elegemos o romance como objeto de estudo, mediante a observação de que, neste gênero, o social e o ideológico se unem sob a forma de diálogo. Assim, suas raízes são fundamentadas nas interações entre o social, o contexto histórico-cultural e vida individual dos sujeitos, revelando a interdependência da relação entre o eu e o outro, transparecendo, no discurso literário, a interpessoalidade.

Também criticando os pensamentos formais daqueles que julgam ser falha a representação da vida pessoal do escritor em sua obra, Ariano Suassuna (1969) afirmou que a crítica literária separa e se rebela contra a obra que represente o social através da relação entre obra e vida do escritor. A obra de Ariano Suassuna, sob uma visão geral, é conhecida pela representatividade cultural e valorização da cultura brasileira concretizada na participação política e no ideário do Movimento Armorial ${ }^{1}$, não distanciadas do contexto social do autor. Pode-se afirmar que não é aceitável a não-relação entre contexto social, autor e obra, pois não é possível desvencilhar a vida de um artista de sua arte e criação. 1 O Movimento Armorial, criado em 18 de outubro de 1970, tem por objetivo valorizar, defender e divulgar a
cultura popular. A manifestação da brasilidade, da nordestinidade nos modos de fazer arte. 
Sobre o romance, Suassuna (1969) enuncia que o exterior (contexto social) tem importância na estrutura e estilo do gênero, isso porque o romance revela e desencadeia um universo psicológico dos personagens, conflitos, problemáticas sociais e projeções com o cotidiano. Boa parte da obra de Ariano dialoga com textos canônicos da literatura universal e também da cultura popular, abordando dialogicamente o regional e o universal unindo o erudito e popular.

Destacamos a necessidade de se investigar os sentidos construídos pelo diálogo entre enunciados, considerados como elementos representativos das múltiplas vozes que interpelam um determinado discurso, sendo este compreendido através das relações dialógicas entre os enunciados constitutivos de um romance.

Nesta pesquisa, fundamentada na teoria dialógica de Bakhtin, o romance de Ariano Suassuna representa um arcabouço de traços ideológicos que compõem a sua construção, trazendo à tona a noção de enunciados dialógicos. Suassuna (1994), leva seu leitor a recuperar traços de outros enunciados antecedentes a sua criação, ou seja, traz, a partir do seu romance, o medieval, representado pelas históricas clássicas dos romances com que dialoga. Pretende-se analisar, como objeto de estudo, o romance $A$ bistória do amor de Fernando e Isaura (1994) de Ariano Suassuna, em diálogo com um mito celta representado pelos romances: Tristão e Iseu (1976), de Joseph Bédier (versão traduzida de Afrânio Peixoto) e Tristan et Iseut (1903), de Béroul, evidenciando as relações dialógicas que o constituem e as características que tornam o romance suassuniano plural, particular, cultural e popular.

O desenvolvimento desta pesquisa nos permitiu compreender a inseparável ligação entre o romance e as relações dialógicas. Tal ligação circunscrita em um contexto literáriocultural permitiu-nos oportunizar e valorizar a obra de Ariano Suassuna, A história do amor de Fernando e Isaura (1994), bem como o seu contexto de criação representado pelo Movimento Armorial.

\section{As relações dialógicas e o romance: apontamentos bakhtinianos}

Mikhail Bakhtin concebe a linguagem como lugar de interação, que não é representada e formada apenas por um sistema abstrato, mas que é vista como criação coletiva, 
resultante do diálogo e da interação (relação entre o eu e o outro). O teórico russo (2011) postula uma concepção de língua situada nas funções sociais e comunicativas da linguagem humana, assim, afirma que a língua, enquanto fenômeno, não pode desvincular-se do seu caráter social e dialógico. Desse modo, é preciso pensar o homem na sua relação com o outro, sendo importante a reflexão de que o indivíduo é social e firma-se como verdadeiramente humano na relação cotidiana, isso porque, conforme Bakhtin (2011), a experiência verbal individual do homem toma forma e evolui sob o efeito da interação contínua e permanente com os enunciados individuais do outro.

Bakhtin (2011, p. 348) afirma que "a vida é dialógica por natureza. Viver significa participar do diálogo". Eis o princípio dialógico que é eleito como fio condutor do desenvolvimento de toda a teoria bakhtiniana e, como tal é considerado como princípio constitutivo da linguagem. Tal princípio é característica indissociável da linguagem permitindonos observar a própria linguagem, como lugar de retomada do sujeito histórico-social-discursivo, e entendendo-a como lugar de interação.

É possível observar que a concepção de linguagem bakhtiniana reflete, concomitantemente, a obra como um todo e, privilegia noções muito particulares e constitutivas desse todo. Em todo o percurso dos estudos de Bakhtin, não é comum encontrar noções de língua e linguagem que sigam uma estrita linearidade, ou seja, que não se conduzam a um movimento dialógico que suscite atitudes de responsividade no leitor e, em outras palavras, que fujam a movimentos de respostas à teoria. Esta atitude leitora não é tão simples, daí as várias possibilidades de estudos a serem explorados nessa teoria, como o estudo dos vários gêneros discursivos, a questão estilística no ensino de língua, o estudo da dialogícidade do gênero, entre outros.

Para refletir sobre a determinação dialógica, ou mais precisamente sobre o termo dialogismo, é preciso partir das considerações de Bakhtin (2011), em que ele considera o princípio dialógico como sendo constitutivo da concepção de linguagem. Tal princípio surge como condição de existência para os sentidos do discurso, e revela as relações entre vida e linguagem. Quando pela reflexão bakhtiniana, ultrapassam-se os limites linguísticos, 
e a enunciação é evidenciada pelas determinantes relações sociais, surge uma categoria básica, ou melhor, essencial para a elaboração desta reflexão, o dialogismo. A palavra é compreendida como referência fundamental para o entendimento do dinamismo que pressupõe o dialogismo. A palavra acumula sentidos sem, portanto, repeti-los.

\begin{abstract}
Não existe a primeira nem a última palavra, e não há limites para o contexto dialógico (este se estende ao passado sem limites e ao futuro sem limites) Nem os sentidos do passado, isto é, nascidos no diálogo dos séculos passados, podem jamais ser estáveis (concluídos, acabados de uma vez por todas): eles sempre irão mudar (renovando-se) no processo de desenvolvimento subsequente, futuro do diálogo. Em qualquer momento do desenvolvimento do diálogo existem massas internas e ilimitadas de sentidos esquecidos, mas em determinados momentos do sucessivo desenvolvimento do diálogo, em seu curso, tais sentidos serão relembrados e reviverão em forma renovada (em novo contexto) Não existe nada absolutamente morto: cada sentido terá sua festa de renovação. (BAKHTIN, 2011, p. 410)
\end{abstract}

Do mesmo modo que a palavra, o diálogo não é detentor de um começo exato ou de um preciso fim de sentidos. É no diálogo que se recriam os sentidos e que estão presentes as características de pluralidade e multiplicidade, isso porque, o diálogo é tido como inconcluso, infindável e os seus sentidos não se esgotam e nem se limitam. A colocação da palavra sem limites primeiros e últimos determina o conceito de dialogismo.

Bakhtin, inicialmente em Problemas da poética de Dostoiévski (2015), através da orientação dialógica, estudou as particularidades e características da linguagem. Quando Bakhtin (2015) elege o discurso como objeto de estudo, ele determina que a língua deve ser definida em sua integridade concreta e não especificamente como objeto da linguística. O seu interesse por análises realizadas no contexto dialógico, fez com que passasse a entender por dialogicidade o conceito nominado de relações dialógicas.

As relações dialógicas passam a orientar e determinar as análises no plano discursivo, que tem como base a teoria bakhtiniana. Nesta perspectiva, conforme Bakhtin (2010, p. 184) “as relações dialógicas são absolutamente impossíveis sem relação lógica e concretosemântica, mas são irredutíveis a estas e têm especificidade própria”. Em outras palavras, as relações dialógicas não se limitam à logicidade e, compreendidas discursivamente, na 
língua concreta, não desconsideram também as relações lógicas, gerando tensões entre relações dialógicas e relações lógicas, mostrando que a existência da linguagem ganha vida e dinamicidade na comunicação dialógica e de sentidos.

As relações dialógicas são de índole específica: não podem ser reduzidas a relações meramente lógicas (ainda que dialéticas) nem meramente linguísticas (sintático-composicionais) [...] As relações dialógicas são relações (semânticas) entre toda espécie de enunciados na comunicação discursiva. (BAKHTIN, 2011, p. 323, grifo do autor)

É através das relações dialógicas que a enunciação sustenta as relações e organiza o meio social de um sujeito, marcando no campo enunciativo e discursivo todos os componentes da interação verbal. Muito mais do que priorizar apenas signos, a enunciação contextualizada dialogicamente suscita relações dialógicas.

As relações dialógicas são possíveis não apenas entre enunciações integrais (relativamente), mas o enfoque dialógico é possível a qualquer parte significante do enunciado, [...] se ouvimos nela a voz do outro. Por isso, as relações dialógicas podem penetrar no âmago do enunciado. [...] por outro lado, as relações dialógicas são possíveis também entre estilos de linguagem, os dialetos sociais, etc. [...] Por último, as relações dialógicas são possíveis também com a sua própria enunciação como um todo, como partes isoladas desse todo e com uma palavra isolada nele. [...]. (BAKHTIN, 2015, p. 210-211)

As relações dialógicas se determinam pela posição interpretativa e pelo contexto discursivo, conduzindo, portanto, para compreensão da obra literária. Os sentidos atribuídos aos enunciados constitutivos de um gênero engendram-se por possibilidades reais da enunciação e através de vozes que povoam o tecido da linguagem, sendo assim, as relações dialógicas responsáveis pela ligação dialógica entre esses sentidos nos enunciados. O movimento de compreensão de um gênero se dá, também, por meio das relações dialógicas, assim, é possível pensar na relação existente entre o eu e o outro, e no resgate dos sentidos que significam no contexto imediato promovido pelos diálogos nas relações.

Assim, o que Bakhtin (2014) denomina serem relações dialógicas em um romance, passa a ser revelado através da relação que o discurso de um autor mantém com outros 
discursos de outros autores e em outras obras, melhor dizendo, as relações dialógicas fundamentam os romances em questões temáticas de interações sociais e culturais e de procedimentos textuais. Essa cadeia, formada por essas relações, torna-se ininterrupta e as interações que foram construídas socialmente tornam-se não penetráveis, pois o contexto dialógico é infinito e o fio que o orienta e o interliga é contínuo.

Bakhtin $(2011,2014)$ elege o romance como gênero-subsídio para observação e estudo do desenvolvimento e da evolução da língua. Enquanto gênero narrativo majoritariamente teorizado, o romance é caracterizado por sua não consolidação, ou seja, quando se resgata o percurso evolutivo do gênero romanesco, aponta-se que não existem fórmulas e métodos que consigam descrever e limitar o gênero a determinadas características formais.

Um gênero surge trazendo como base elementos culturais, costumes e tradições, contudo, simultaneamente, revela o novo através de sua estrutura e do modo com que apreende a realidade. Nesse sentido, o romance quando molda e relaciona etapas sociais, culturais e históricas com estruturas e formas, tanto pode convencioná-las como refutá-las. Bakhtin (2014) reflete que o romance é um gênero aberto e inacabado ora por questões temáticas, ora por questões composicionais. Desse modo o romance não é pensado sob a possibilidade de acabamento e esgotamento, visto que, justamente, pelo seu inacabamento estrutural é que surgem novas formas e composições que permitem constante renovação.

Quando Bakhtin (2014, p. 420) afirma que "o caráter de imutabilidade semântica do objeto: o seu sentido e o seu significado se renovam e crescem à medida que esse contexto se desenvolve posteriormente", ele eleva a supremacia do romance quanto à significação e como crítica característica de outros gêneros literários, através da representação do mundo, como "gênero-mestre da nova literatura" (BAKHTIN, 2014, p. 403).

É importante observar que, ao elencar uma espécie de cronologia que abarca as publicações literárias, a teoria do romance se concretizou enquanto ponto de interesse de estudos, especialmente, na Europa. Relacionada ao advento do romance, destaca-se que as primeiras publicações romanescas surgiram no limiar do século XVIII, ganhando corpo em meados do final do século XIX, com o apogeu do romantismo. 
Bakhtin (2014), em Epos e Romance (p. 397-428) afirma que a existência histórica do romance não se dá mediante moldes, ossaturas e acabamentos, assim como são constituídos os gêneros mais velhos, tal como a epopeia e a tragédia. Ao lado destes gêneros, apenas o romance é considerado mais jovem, por ser um gênero em constituição e, portanto, inacabado. Desse modo, conforme Bakhtin (2014, p. 397), "a ossatura do romance enquanto gênero ainda está longe de ser consolidada", sendo análogo ao estudo das línguas mortas em comparação com outros gêneros, pois se preocupa em representar as línguas vivas.

Apesar de o romance narrar, também, o passado, ele o narra para significar este passado no presente. Assim, a modernidade está na representação literária do romance que passa a configurar conhecimento do homem e do mundo, através da adaptação do objeto de representação artística, que se nivela à realidade e ao inacabamento. Isso representa a capacidade que o romance tem de conceber a transitoriedade da vida sob percepções novas de tempo e espaço que não tiveram vez e destaque na antiguidade. O romance é, portanto, o gênero da modernidade ${ }^{2}$.

\section{A história do amor de Fernando e Isaura em relações dialógicas: conteúdo temá- tico, estrutura composicional e estilo}

Seria ingênuo imaginar que Shakespeare foi o primeiro a escrever a história de dois jovens que viviam e nutriam uma paixão impossível de se sustentar. Muito antes de Romeu e Julieta, ou ainda, antes de Lancelot e Guinevere, Tristão e Iseu (Tristão e Iseu, para as versões mais recentes, ou Tristan et Iseut na versão de Béroul) surgiram como personagens pioneiros e protagonistas da história de um ardente e impossível amor-paixão, transformando a maneira de se pensar o amor quando comparado aos moldes atuais.

O romance que narra o amor jovial, escrito por Béroul (O romance de Tristão), possibilitou a disseminação do mito de Tristão e Iseu, incialmente escrito sob a configuração de 
poema e popularizado por meio de peças teatrais, óperas, filmes e versões diversas que concebiam, em linhas gerais, um triângulo amoroso em tempos medievais. De outro modo, o romance $A$ bistória do amor de Fernando e Isaura, de Ariano Suassuna, se consolidou na cultura popular brasileira como uma espécie de versão nordestina do mito narrado no romance de Tristão e Iseu. Suassuna já justifica a versão, no início do referido romance, em advertência, termo que intitula e anuncia a inspiração para escrita de sua referida obra, comprovando que a escrita desta obra se deu pelo intuito de exercitar o gênero romance.

Em 1956, eu já começava a sonhar com aquele que, depois, seria o Romance d'A Pedra do Reino. Estava um pouco intimidado pelo sonho e pelo impulso que o determinara. E como, até ali, somente escrevera poesia e teatro, resolvi, antes de tentá-lo avaliar e exercitar, numa história curta, as forças de que dispunha para a empresa. Ao mesmo tempo, meu amigo Francisco Brennand sugeria que eu escrevesse uma versão brasileira do Romance de Tristão e Iseu, história que há muito tempo ele desejava ilustrar. Foi, então, daí que surgiu, naquele ano, A história do amor de Fernando e Isaura. Sou um escritor de poucos livros e de poucos leitores. (SUASSUNA, 1994, p. 11)

Quando confessa essa ação, Ariano Suassuna confia à obra um valor e essencialidade de algo antigo, mais adiante denominado de "arcaicos escrúpulos" de forma a denominar-se apenas como coautor da história narrada. Suas confissões no início do romance exemplificam e norteiam a realização do princípio dialógico bakhtiniano, tanto pelos enunciados que se adaptam ao ambiente nordestino transformando os contextos discursivos representados pelos valores e costumes através das relações dialógicas que mantém, apesar das diferenças, quanto pela visão que se tem do autor-escritor (Ariano Suassuna) enquanto instância criativa formada por criatividade e subjetividades.

Assim, Suassuna (1994) toma como base de referência o romance de Tristão e Iseu, que é formado por resíduos de textos medievais e pelo mito de Tristão, de origem celta. Suassuna ao filiar-se aos valores antigos, talvez até considerados arcaicos na sociedade atual, rememora-os e estima sua importância frente à resolução dos atuais conflitos paixões da juventude. Ao escrever A bistória do amor de Fernando e Isaura (1994), Ariano atualiza o mito representado pelas narrativas da história de Tristão e Iseu (1903, 1976) retomando aspectos 
e reminiscências do medievo. Ele se utiliza de diversos recursos de aproximação entre sua obra e as obras com que dialoga, os quais já podemos inicialmente elencar: ambientações, os nomes dos personagens, desenvolvimento dos enredos e valores morais.

Ainda que grande parte do fazer literário de Ariano Suassuna esteja ligada ao teatro, A bistória do amor de Fernando e Isaura (1994) se diferencia das suas demais obras por não tomar o sertão como pano de fundo para suas ambientações, bem como foge aos gêneros teatrais e configura a escrita romanesca. Ainda assim, percebemos neste romance, a intensidade das tragédias e sentimentos, da mesma maneira que nas obras teatrais.

Também observamos que os seguimentos das peripécias e resolução das complicações acontecem do mesmo modo como numa peça teatral. Além disso, destacam-se as ambientações que se tornam diferentes pelos tons contemplativos em conjunto com a ausência de regionalismos configurando uma nova narrativa amorosa, trágica e, ao mesmo tempo, pura e sensual. Dentre tantas diferenças e essencialidades que tornam particular a referida obra, a medievalidade se faz característica presente não só nela, mas em toda a herança literária de Ariano Suassuna, assim como também é marcante na obra que ele toma como referência para a escrita de seu romance. O romance tem um estilo de escrita romântica, sem, contudo, fugir às inspirações com características medievais porque, de forma implícita, busca resgatar o culto da tradição, a crença religiosa, a situação social e os valores que hoje julgamos ultrapassados. Ao conservar o fim trágico em seu romance, Ariano Suassuna, leva-nos também a refletir sobre a finitude da vida da nossa incompletude ao tentar entendê-la.

Ao relacionarmos dialogicamente $A$ bistória do amor de Fernando e Isaura (1994) e o mito de Tristão representado pelos romances Tristão e Iseu e Tristan et Iseut, percebemos que as grandes obras vivem em um contexto dialógico que permite com que elas se perpetuem e permaneçam vivas no imaginário literário, seja de forma original tal como foram escritas; seja através das versões mais recentes que adaptam os contextos mais antigos aos atuais, com detalhes diferentes, mas que mantêm a essência da obra original. São os valores morais, que eram predominantes na época medieval, que regem as narrativas Béroul (1903), Bédier (1976) e Ariano Suassuna (1994). Esses valores constroem os personagens e determinam 
as questões que se destacam no decorrer das narrativas, referentes assim, ao amor, às tradições, às traições e à honra. É a partir desses valores que se inicia o movimento de análise e aproximação dos romances, construindo assim, uma relação entre os princípios que estão arraigados aos personagens bem como uma relação entre o medievo e as terras nordestinas.

Predominavam, na Europa do século XII, conflitos constantes sobre a liberdade que deveria se conferir ao amor físico, sem que essa concessão deturpasse e perturbasse a ordem religiosa. A igreja limitava as práticas sexuais por meio do "matrimônio sacralizado" e, ao mesmo tempo, o contexto matrimonial permitia o casamento a apenas um dos filhos homens, dessa forma os outros, por não possuir esposas legítimas, buscavam satisfações outras que não eram bem vistas aos olhos da igreja.

Surgiu, com esses acontecimentos, a necessidade de uma conduta de comportamento que regesse a sociedade em geral e, principalmente, que codificasse as relações entre homens e mulheres. Enquanto os cristãos da época consideravam a mulher como ser inferior ao homem, os pilares do casamento construíam-se sobre a base da submissão feminina. Foram justamente as relações entre homens e mulheres que fizeram surgir as práticas de amor que tanto se regiam pela pureza e convenções socais (amor cortês), quanto pela natureza da carne (amor-paixão).

Em Tristão e Iseu, são facilmente confirmadas tais observações, tendo em vista que cercam a narrativa, questões referentes à traição de Iseu e às suas origens celtas quando se observa sua inteligência na arte de tratar de poções e unguentos curativos, o que se opunham aos preceitos cristãos da época. Tais observações também se confirmam em $A$ história do amor de Fernando e Isaura (1994), em que acontece a paixão proibida entre os amantes com exceção do filtro mágico ${ }^{3}$, mas que também Isaura tem atitudes espelhadas em Iseu. Ambas as personagens representam, de modo geral, intriga, delicadeza e sutileza. Como se observa

\footnotetext{
${ }^{3}$ Os filtros mágicos em Tristão e Isolda assumir a função outrora representada na cultura celta pelas “geis”, espécie de interdição, constituía um conjunto completo de proibições obrigações que um druida impunha a um indivíduo [...]; ou que uma mulher lançava sobre o homem amado, não só abrigando-o a atendê-la, mas também a assumir o amor e, consequentemente, o seu destino. (MOREIRA 2010, apud, BARROS, 1996, p. 24)
} 
no Quadro 1, os enredos se entrecruzam fazendo com que se aproximem as narrativas dos romances:

\section{Quadro 1 - Enredos}

\begin{tabular}{|l|l|}
\hline \multicolumn{1}{|c|}{ Tristan et Iseut / Tristão E Iseu } & \multicolumn{1}{c|}{ A história do amor de Fernando e Isaura } \\
\hline $\begin{array}{l}\text { Apesar de manter um relacionamento } \\
\text { amoroso com Tristão, Iseu casa-se com }\end{array}$ & $\begin{array}{l}\text { Isaura casa-se com Marcos sem o amar, e muito antes, apai- } \\
\text { xona-se por Fernando sem saber quem ele era e seu grau de } \\
\text { parchtesco com Marcos. }\end{array}$ \\
$\begin{array}{l}\text { Tristão, sobrinho de Marc, também pos- } \\
\text { sui linhagem real e terras que conquistou, } \\
\text { por direito, em nome de seu pai. }\end{array}$ & $\begin{array}{l}\text { Farnando por ser sobrinho de Marcos, é Herdeiro da fazenda } \\
\text { ridade social em relação à Isaura. }\end{array}$ \\
$\begin{array}{l}\text { Iseu mantém por Marc um amor cortês } \\
\text { e, por Tristão, um amor-paixão. }\end{array}$ & $\begin{array}{l}\text { Assim como no romance de Bédier, Isaura e Fernando também } \\
\text { cultivam um amor-paixão ao entregarem-se de corpo e coração. }\end{array}$ \\
\hline
\end{tabular}

Fonte: Elaboração nossa

Na obra de Béroul, as aproximações de enredo mantêm a mesma linha do romance de Bédier. Desse modo, concluída uma contextualização inicial das obras que dialogam, partimos da determinação do gênero discursivo para desconstruir, para esse recorte de análise, as unidades mínimas dos romances em questões de componente do gênero: conteúdo temático, estrutura composicional e estilo.

O encontro de temáticas como amor, erotismo, destino, tragédia, morte, mentira, fidelidade e traição, leva-nos a compreender que, embora nos romances, alguns elementos insurjam de maneiras diferentes nas narrativas, a essencialidade temática os interliga e os torna arraigados. Isso confirma a afirmação de Ariano Suassuna, a qual nos referimos no início da seção e, reitera nossa compreensão no que respeita a presença e o funcionamento das relações dialógicas no interior dos romances.

Dentre os temas de diálogos, a primeira temática que aproxima o romance $A$ história do amor de Fernando e Isaura, do romance Tristão e Iseu, e da primeira versão conhecida escrita do mito, Tristan et Iseut. Todas as narrativas famosas e bem sucedidas em relação às suas temáticas abordam, direta ou indiretamente, o amor. Ambos os romances exploram conflitos entre diferentes tipos de relação de amor, transformando conyenções como, por exemplo, o casamento, de maneira que leva a refletir sobre o casamento como relação contratual entre famílias para uma relação de amor entre dois indivíduos. 
O que é o amor? Visto sob os pilares constitutivos no romance Tristão e Iseu, o amor vem a ser resultado de uma poção ${ }^{4}$ mágica (de ervas), uma mistura entre o místico e a vontade de verdade pregada pelas famílias ao organizar e arranjar um casamento contratual. Em Tristan et Iseut o amor ora é convenção, ora é descoberta. Isso porque, na época em que está contextualizado, o amor sobrevivia a grandes conflitos e imposições sociais e é amor vertido em paixão que faz com que os jovens se aproximem. Já em Fernando e Isaura, o amor surge pela atração natural entre os amantes e perdura apesar da distância. De qualquer forma, uma lição é aprendida por meio da leitura de tais romances, e da leitura da versão original francesa: o amor pode nos fazer impotente frente à aceitação e resistência dos nossos destinos.

Assim, podemos afirmar que, em relação a estas temáticas anteriormente elencadas, os romances mantêm, ao logo de seus enunciados, relações dialógicas fortemente marcadas. São essas relações que fazem do romance de Ariano Suassuna uma versão nordestina do romance de Tristão e Iseu e do romance de Tristan et Iseut, aproximando-os em questões temáticas e, principalmente, em referência ao amor. Ariano Suassuna, ao elencar uma série de acontecimentos, recontextualiza a menção ao fantástico tal como acontece no mito celta e, o destino dos personagens serve como estratégia para aproximação temática de uma história, do que o próprio Ariano julga como sendo "fora de moda" (SUASSUNA, 1994, p. 12). Talvez esse julgamento sobre o amor, como tal representado em Fernando e Isaura, advenha da contemporaneidade e, portanto, tenha se tornado incompreensível pela sua liquidez e pelas atitudes valorativas decorrentes da inconstância da atual sociedade.

Para compreendermos o processo de estrutura composicional dos romances, destacamos inicialmente a versão mais antiga do mito de Tristão (de Béroul) e a versão de Bédier (versão brasileira de Afrânio Peixoto) e em sequência a versão de Ariano Suassuna.

${ }^{4}$ CUNHA (1982, p. 616) "medicamento líquido, para se beber, qualquer bebida."

(FERREIRA, 2010) "1. Farm. Hidrólio que contém medicamento dissolvido ou em suspensão, para ser administrado por via oral., Qualquer bebida.” Disponível em: https://contas.tcu.gov.br/dicionario/home. aspv. Acesso em: 25 abr. 2020 . 
A primeira configuração estrutural da obra de Béroul, que pode ser considerada uma sequência linear, cronológica e encadeada dos episódios. Em linhas gerais, o romance organiza-se a partir nascimento de Tristan, da relação entre Tristan e Iseu, da relação Tristan, Iseu e Marc e exílio e retorno de Tristan até a morte dos amantes.

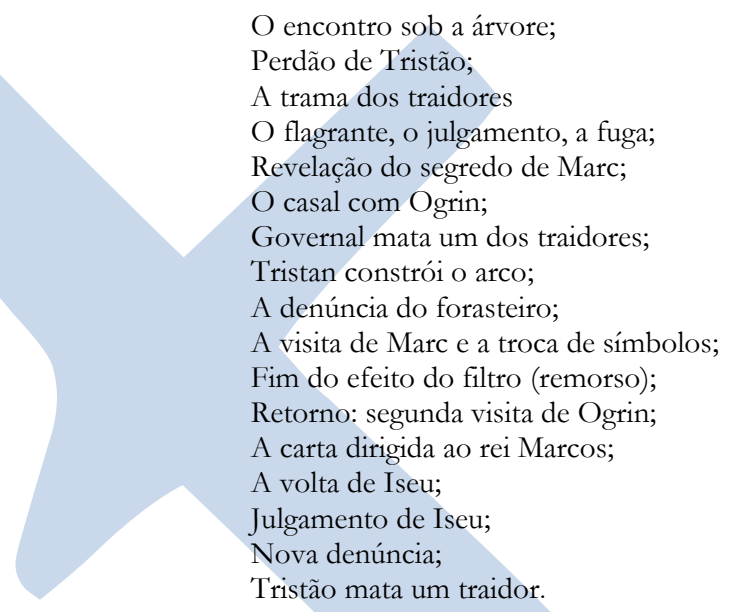

Todo o desenvolvimento da trama segue uma sequência de articulação literária entre o feudalismo, a monarquia e os elementos cristãos. Os elementos da narrativa, que se norteiam por essas articulações, permitem diversos modos de compreensão da obra e do significado do propósito do romance. Béroul une temporalidades e matizes culturais para narrar a grande questão do amor daquela época.

Há uma particularidade essencialmente distintiva entre o romance de Béroul e a versão de Bédier, quanto a sua estrutura composicional, a obra é estruturada em versos: ela é composta aproximadamente por 4.500 versos.

A configuração estrutural da obra de Bédier, também sob o aspecto da sumarização, se organiza em dezenove capítulos:

I. As infâncias de Tristão;

II. O Morholt da Irlanda;

III. Em busca da Bela dos cabelos de ouro;

IV. O filtro; 
V. Briolanja entregue aos servos;

VI. O grande pinheiro;

VII. O anão Frocino;

VIII. O salto da capela;

IX. A floresta do Morois;

X. O eremita Ogrino;

XI. O Vau Arriscado;

XII. O julgamento pelo ferro em brasa;

XIII. A voz do rouxinol;

XIV. O guizo maravilhoso;

XV. Iseu das Brancas Mãos;

XVI. Caerdino;

XVII. Dinas de Lidano;

XVIII. Tristão louco;

XIX. A morte.

Apesar do distanciamento aparentemente e estrutural, pelo fato do romance ser escrito em prosa, Bédier segue de forma legítima os mesmos momentos que servem como chave para o desenvolvimento do mito que vai do nascimento de Tristão até a morte dos jovens amantes. Todas as vezes que aparecem as atuações de Tristão e Iseu percebemos a relação entre o amor trágico e ao mesmo tempo absoluto.

Em ambos os romances, podemos afirmar que o amor é representado em uma sequência de episódios que são resultados de rupturas e negações, dado que, de certa forma, o cultivo do amor entre os jovens representa deslocamento em relação aos princípios sociais de realidade. O narrador também é a peça essencial para a estruturação do texto, porque ele constrói singularidades a partir de seus posicionamentos frente às temáticas e participação ativa na construção da trama. Autor e narrador, no âmbito dos romances de Tristan et Iseut (Béroul) e Tristão e Iseu (Bédier) são indissociáveis no sentido em que os comentários que os narradores fazem no decorrer da obra também representam o contexto histórico do autor.

Conforme o que já foi discutido na seção anterior, pudemos perceber que o romance $A$ bistória de amor de Fernando e Isaura mantém relações dialógicas em sentido temático com os romances Tristan et Iseut e o romance Tristão e Iseu. Do mesmo medo, podemos 
reafirmar a validade dessas relações, quando vemos que a estrutura composicional do romance de Ariano Suassuna relaciona-se com a narrativa de Bédier que, por sua vez, mantém relações com a narrativa de Béroul.

Nessa tessitura de relações, a afirmação que o próprio Ariano Suassuna faz nas páginas iniciais do romance sobre sua obra, afirmando ser uma imitação nordestina de Béroul, Bédier e Afrânio Peixoto (1976), faz-nos resgatar o mesmo percurso histórico e contextual, o qual tecemos no início desta seção. Desse modo, Ariano sempre esteve preocupado em resgatar os valores dessas obras que retratavam a sociedade medieval. Ainda assim, acrescemos algumas considerações que dizem respeito à construção estrutural de sua obra.

O romance de Fernando e Isaura é o primeiro da carreira de Ariano Suassuna e serviu como subsídio para exercício da escrita deste gênero e, do que mais tarde viria a ser uma das mais importantes obras de sua vida, O romance d'Pedra do Reino. Sumariamente, o romance de Fernando e Isaura está assim organizado:

\author{
São Joaquim \\ Uma Revelação \\ Uma Conversa Penosa \\ A Viagem \\ O Encontro \\ O Rio \\ A Festa \\ Uma Noite de Amor \\ Tristes Resoluções \\ O Casamento \\ A Volta \\ A Noite de Núpcias \\ Mentira e Piedade \\ Heroica Resolução \\ Quanto Pode a Virtude \\ Uma Dama Virtuosa \\ Um Homem Generoso \\ A Espada e o Anjo \\ Desterro \\ Com o Suor de Seu Rosto \\ Almas Sensíveis \\ Solidão em São Joaquim \\ Tratado de Paz \\ Entrevista
}




\author{
De Novo em Casa \\ Isaura, a das Brancas Mãos \\ Duplo Engano \\ Uma Voz do Passado \\ Conversa Conjugal \\ Promessa de Amigo \\ A Bandeira \\ A Chegada \\ Derradeira Entrevista \\ Viagem Final
}

A estrutura do referido romance também é constituída dos episódios que conduzem ao fim trágico dos jovens amantes, o que diferencia a obra e Suassuniana dos outros romances é o fato das ações dos personagens tomarem formas diferentes no desenvolvimento da narrativa, agindo por motivações distintas e ainda, por se passar em ambientes e tempos diferentes. Mas o que se destaca como beleza e reafirmação da estrutura narrativa relacionada dialogicamente aos outros romances é a arte do narrador (Ariano Suassuna) de tramar uma narrativa a partir de diversos modos de criação, mas que ambos se interligam ao texto de origem e inspiração.

Assim sendo, apesar da semelhança estrutural da narrativa, o narrador se utiliza de amplificações, extrapolações e recontextualizações que caracterizam originalmente a versão brasileira do mito de Tristão. Ariano Suassuna reconfigura o mito de Tristão para que, conforme ele mesmo demarcou no início do romance, seja minimizada a distância da narrativa com a cultura que ele pretende representar.

Ao reunirmos reflexões relacionadas ao simbolismo, imaginário popular, alegorias, estilo de escrita, personagens e relações dialógicas, compreendemos que esses elementos constroem os estilos dos romances. Já demarcamos nas seções anteriores que os autores, Ariano Suassuna, Bédier e Béroul, produziram romances que se propuseram a retratar o mito de Tristão e que o romance de Fernando e Isaura se diferenciava dos outros romances estudados em questões ligadas, sobretudo, ao imaginário popular Nordestino. Estas diferenças são marcadas nas particularidades de escrita e estilos pessoais que também são influenciados pelas épocas de vivência e criação dos autores. As marcas que determinam todo o processo de construção estilística entre os autores são singulares. 
Nos três romances, percebemos que os autores posicionam-se, tanto em relação às temáticas, quanto às suas tradições orais e escritas que trouxeram como referências. Assim sendo, através do modo de construção do narrador e, ao mesmo tempo, do posicionamento dos autores nos romances, é possível demarcar a participação ativa de cada um na trama romanesca.

Bédier (1976) e Suassuna (1994) se posicionam enquanto sujeitos conhecedores de narrativas anteriores que tratavam do mesmo mito ao demarcarem suas posições a partir dos prefácios e notas do autor. Também percebemos o posicionamento dos autores quando se colocam como juízes dos personagens, de forma que levam os leitores a também construírem juízos de valor. Em Bédier (1976) destacamos:

Quadro 2- Estilo de Bédier

\begin{tabular}{|c|c|c|c|}
\hline \multicolumn{2}{|l|}{ Posicionamento pessoais } & $\begin{array}{l}\text { Participação ativa na } \\
\text { trama }\end{array}$ & Realidade histórica \\
\hline \multicolumn{2}{|c|}{$\begin{array}{l}\text { [...] obter sobre mim mesmo, a custo de simpatia } \\
\text { histórica e crítica, de jamais misturar as concep- } \\
\text { ções modernas às antigas formas de pensar e de } \\
\text { sentir - tal foi meu desígnio, meu esforço e, } \\
\text { sem dúvida, - ai de mim! - minha quimera. } \\
\text { Mas meu texto é muito composto e se quisesse, } \\
\text { por miúdo, indicar minhas fontes, seria mister } \\
\text { pôr embaixo das páginas deste livro tantas notas. } \\
\text { (BÉDIER, 1976, p. 11) }\end{array}$} & $\begin{array}{l}\text { Senhores, convém ao } \\
\text { narrador que deseja } \\
\text { que deseja agradar, } \\
\text { evite longas digressões. } \\
\text { É tão bela e tão diversa } \\
\text { a matéria deste conto! } \\
\text { (BÉDIER, 1976, p. 18) }\end{array}$ & $\begin{array}{l}\text { Muito tempo há, reinava } \\
\text { el-Rei Marc em Cornualha. } \\
\text { Sabendo que guerreavam } \\
\text { inimigos, Rivaleno, Rei de } \\
\text { Leonis, atravessou o mar, } \\
\text { para lhe prestar ajuda. (BÉ- } \\
\text { DIER, 1976, p. 13) }\end{array}$ \\
\hline $\begin{array}{c}\text { Posicionamento de juízo } \\
\text { de valor }\end{array}$ & & \multicolumn{2}{|c|}{ Posicionamentos pessoais e narração } \\
\hline $\begin{array}{l}\text { Mas nem ele, nem ela pesar de tan- } \\
\text { tos encontros e acordos de ânimo, } \\
\text { pudera sequer fingir na fantasia o } \\
\text { que o destino lhes reservava... } \\
\text { (BÉDIER, 1976, p. 36) }\end{array}$ & \multicolumn{3}{|c|}{$\begin{array}{l}\text { Ouvide e sede compassivos: não os culpeis, porque, assim a morte, } \\
\text { é também fatal o amor... (BÉDIER, 1976, p. 40) } \\
\text { Não tem todas as coisas, boas ou más, seu arrependimento? ... (BÉ- } \\
\text { DIER, 1976, p. 45) } \\
\text { Começou então para os fugitivos, no fundo da selva selvagem, vida } \\
\text { áspera, porém vida amada. E não tinham tudo, tendo o amor? ... } \\
\text { (BÉDIER, 1976, p. 65) }\end{array}$} \\
\hline
\end{tabular}

Fonte: Elaboração nossa

Os posicionamentos pessoais em Bédier partem, inicialmente, de observações que ele faz em seu prefácio adicional, de forma que informa e atualiza o leitor sobre a construção do seu texto. Também destacamos participações do autor na trama, quando ele toma a posição do narrador e profere conselhos e observações como é possível perceber a reali- 
dade história na qual o romance está situado por meio de palavras que a delimitam. Tomando como exemplo, as palavras: rei, guerras, barões e duque, é possível situar, para o leitor, a época em que o romance está inserido: um período pré medieval, estabelecido entre poderes monárquicos e a barbárie.

O juízo de valor e os posicionamentos pessoais constituem, de forma muito marcada, o estilo de escrita de Bédier. Ao fim de cada capítulo, Bédier (1976) profere uma frase que indica posicionamento/juízo de valor. Tal frase é constituída de toques pessoais que tornam a narrativa intrigante e contínua, ao passo que, cada frase, anuncia e resume o que tratará o próximo capítulo.

Assim, ao longo do romance, é comum perceber os posicionamentos pessoais misturados às palavras do narrador, fazendo como que se entenda que o próprio autor está presente na trama e pode detalhar, minuciosamente, os acontecimentos.

Os posicionamentos de Suassuna (1994) confirmam um estilo de escrita peculiar:

Quadro 3 - Estilo suassuniano

\begin{tabular}{|c|c|c|}
\hline Posicionamento pessoais & Participação ativa na trama & Realidade histórica \\
\hline $\begin{array}{l}\text { Em 1956, eu já começava a sonhar com } \\
\text { aquele que, depois, seria o Romance d"A } \\
\text { Pedra do Reino. Estava um pouco intimi- } \\
\text { dado pelo sonho e pelo impulso que o de- } \\
\text { terminara. E como, até ali, somente escre- } \\
\text { vera poesia e teatro, resolvi, antes de tentá- } \\
\text { lo, avaliar e exercitar, numa história curta, } \\
\text { as forças de que dispunha para a empresa. } \\
\text { (SUASSUNA, 1994, p. 11) }\end{array}$ & $\begin{array}{l}\text { Chovia continuamente e, nas } \\
\text { noites de temporal, parecia que } \\
\text { as ondas iam invadir a casa, } \\
\text { quebrando-se contra a muralha } \\
\text { de areia da praia. (SUASSUNA, } \\
\text { 1994, p. 13-14) }\end{array}$ & $\begin{array}{l}\text { Na fazenda "São Joa- } \\
\text { quim", [...] de lavouras } \\
\text { diversas por trás da es- } \\
\text { trada. (SUASSUNA, } \\
\text { 1994, p. 15, grifo nosso) }\end{array}$ \\
\hline Posicionamento de juízo de valor & \multicolumn{2}{|c|}{ Posicionamentos pessoais e narração } \\
\hline $\begin{array}{l}\text { E, para se sentirem um pouco menos cul- } \\
\text { pados, chegavam, mesmo, a dizer e achar } \\
\text { que Marcos é que agira mal, deixando de ir } \\
\text { buscar a mulher por causa de negócios e } \\
\text { adotando aquela singular maneira de casar- } \\
\text { se que terminara por jogá-los um nos bra- } \\
\text { ços do outro. (SUASSUNA, 1994, p. } 67 \text { ) }\end{array}$ & \multicolumn{2}{|c|}{$\begin{array}{l}\text { Enfim, tudo passa neste mundo e a vida, aos poucos, co- } \\
\text { meçou a se tornar menos intolerável para todos. (SUAS- } \\
\text { SUNA, 1994, p. 121) } \\
\text { Não vale como exemplo para ninguém, pois, ao que parece } \\
\text { para nada serve esse amontoado de acontecimentos sem } \\
\text { sentido ao qual ordinariamente se dá o nome de experiên- } \\
\text { cia. Apenas, sagrada e triste, contém ela, em si, a dor, as } \\
\text { lágrimas, a exultação e os extravios - enfim, o bem e o } \\
\text { mal misturados que implica, necessariamente, toda e qual- } \\
\text { quer história de homem. (SUASSUNA, 1994, p. 155) }\end{array}$} \\
\hline
\end{tabular}

Fonte: Elaboração nossa 
Os posicionamentos pessoais em Suassuna são direcionados ao leitor, como forma de levá-lo a compreender as escolhas e posições que o próprio autor assume quando se coloca, em alguns momentos, enquanto narrador do romance. Esses posicionamentos, também, confirmam a participação do autor na trama, pois os elementos temporais e espaciais, do mesmo modo que os estados emocionais dos personagens, são detalhados por alguém (pelo autor enquanto narrador) que está presente ao longo da narrativa.

É importante destacar, como no fragmento acima escolhido, o uso de palavras que delimitam a época, ou seja, a realidade histórica a qual o romance está inserido. Palavras como fazenda, lavouras e boiadas remetem a atividade econômica daquele período e, apesar de 1994 ser o ano marcante para economia e história do Brasil, pela inserção da nova moeda, o real, Suassuna não faz referência nem situa esse acontecimento, de forma a confirmar que o romance demonstra se situar em um tempo um pouco distante da realidade histórica vivenciada pelo autor.

Os posicionamentos de juízo de valor, também inseridos na narração, são bem mais sutis e são facilmente confundidos com a fala do narrador. São esses posicionamentos que tornam singular o romance de Fernando e Isaura, as palavras do autor dão realidade e um verdadeiro tom de vivência daqueles acontecimentos.

De forma individual, o estilo de Ariano Suassuna é demarcado pela busca em perceber e compreender o passado, reinventando-o e fazendo-o conviver com inúmeras temporalidades e diferentes esferas, universos e particularidades. Assim, ele intervém em sua realidade, através das ordens dos acontecimentos ficcionais, juntamente com a realidade histórica que é desvendada por seu diálogo e convivências.

Ele faz submergir o arcaico através da erudição do popular. Ressaltamos ainda, que Ariano Suassuna conservou a estrutura narrativa, as temáticas e os episódios da obra que tomou como base para escrita de seu romance, sendo assim, é até comum que o leitor pense que o próprio Suassuna leu fielmente os romances Bédier e Béroul a ponto de conservar os traços essenciais das obras em seu romance sobre os jovens Fernando e Isaura. 


\section{Algumas considerações}

Verificamos que, tanto o romance A bistória de amor de Fernando e Isaura, quanto os romances de Bédier e Béroul, mantêm uma dialogicidade interna que os organizam e os harmonizam em questões de temáticas, de estruturas e de estilos que se destacam por meio das relações dialógicas. Os movimentos de compreensão (análise) de um gênero, muitas vezes estiveram orientados, no que diz respeito apenas, à classificação e organização de escolas literárias, bem como, às atividades de análise linguística em fragmentos isolados de texto. É por isso que afirmamos que o trabalho metodológico e de compreensão do gênero romance demanda responsividade e responsabilidade. É a noção de arquitetônica permite que, nós pesquisadores, construamos outros modos de olhar as relações entre enunciados e discursos tomando como base a dialogicidade interna que os organiza, caracterizando o movimento de compreensão que gera alteridade e interação.

Desde a tradição oral, passando pelas gerações, o mito de Tristão vem sendo rememorado, de forma que, com o passar dos anos, adapta-se aos novos formatos e formas de abordagem em questão de gênero, perpassando pela fala (oralidade e imaginário popular), pelo canto (óperas e cantatas), a poesia (escrita berouliana), prosa (Bédier, Suassuna), no teatro (diversas representações a partir da tradução de Bédier) e cinema (Kevin Reynolds). Em prosa e poesia, as obras de Béroul e Bédier revelam o mito ante a clandestinidade de um relacionamento amoroso guiado por paixão e desejo, incitados pela mistura em vinho que beberam. O romance em versos de Béroul serve como base para a escrita do romance em prosa de Bédier que, de forma residual, retrata aspectos e valores que estão arraigados à época medieval e ao imaginário celta. Apenas o caráter mítico não daria conta de transpor esses romances ao logo dos séculos tornando a narrativa imortal e perpétua.

Compreendemos o caráter dialógico da obra através dos elementos de atualização e rememoração do mito de Tristão, o que vem reafirmar que as relações dialógicas constituem o referido romance de Suassuna e fazem com que sua versão nordestina se torne um dos romances conhecidos mundialmente pela rememoração literária do mito. Não podemos deixar de destacar um importante traço predominante, não só nesta obra, mas na construção estilística das obras Ariano Suassuna como um todo, quando conhecemos o 
seu contexto de produção literária, a medievalidade rememorada faz com que se resgatem valores esquecidos e abandonados em nossa sociedade atual, bem como também torna singular a escrita suassuniana.

\title{
THE NOVEL A HISTÓRIA DO AMOR DE FERNANDO E ISAURA IN DIALOGICAL RELATIONSHIPS: FROM THE MEDIEVO TO THE NORTHEAST
}

\begin{abstract}
This research deals with the dialogical path that constitutes the formation of the novel A bistória do amor de Fernando e Isaura (1994), by Ariano Suassuna, based on Bakhtin (2014) for whom the novel is a social diversity of languages organized artistically, by languages and individual voices. The study of dialogical relations is an indispensable condition for understanding the meanings that determine the discourse of a genre, in a dialogical perspective. In view of this, the relationships that organize and constitute the novel by Fernando and Isaura are investigated, so that the objective of this research is to understand how dialogical relationships contribute to the formation and understanding of the meanings in a novel. In function of the object of study, a research of descriptiveinterpretative method of qualitative approach is developed, however, the analyzes take as a theoretical-methodological basis, the Dialogic Theory of Language. The theoretical assumptions are the literary review of Bakhtin's works (2011, 2014 and 2015) and Bakhtin / Volochínov (1981). It is understood that the novel can mix, mix and pluralize voices and that the dialogic character that constitutes it, places its languages face to face with the social and real context of the language, through the interaction of spaces and discourses. Fernando Isaura's prosaic novel is synonymous with renewing meanings, since it represents the activity of Suassunian writing and seeks to rescue elements of erudite culture in the novels Tristan et Iseut (1903), by Béroul and Tristão and Iseu (1976), by Joseph Bédier (translated version by Afrânio Peixoto), extolling the popular northeastern imagination.
\end{abstract}

KEYWORDS: Dialogical relations; Romance; Ariano Suassuna; Popular culture.

\section{REFERÊNCIAS}

BAKHTIN, M. Estética da criação verbal. 5. ed. São Paulo: Martins Fontes, 2011. - A cultura popular na Idade Média e no Renascimento: o contexto de François Rabelais. São Paulo: Hucitec, 2013. 2014. - Questões de literatura e de estética: a teoria do romance. 6. ed. São Paulo: HUCITEC, . Problemas da poética de Dostoiévski. Tradução de Paulo Bezerra. 5. ed. Rio de Janeiro: Forense Universitária, 2015.

BÉDIER, Joseph. Tristão e Iseu. Versão Afrânio Peixoto. 5. ed. São Paulo: GRD, 1976. BÉROUL. Tristan et Yseut. Paris: Librarie de Firmin Didot et Cia, 1903. 
CUNHA, Antônio Geraldo da. Dicionário etimológico Nova Fronteira da língua portuguesa. Rio de Janeiro: Nova Fronteira, 1982.

FERREIRA, Aurélio Buarque de Holanda. Dicionário da língua portuguesa. 5. ed. Curitiba: Positivo, 2010. 2222 p. ISBN 978-85-385-4198-1. Disponível em: <https://contas.tcu.gov.br/dicionario/home.aspv> Acesso em: 25 abr. 2020

MOREIRA, Aline Leitão. Tristão e Isolda: em torno do que remanesce. 2010. Dissertação de Mestrado em Letras. Universidade Federal do Ceará - UFC, Fortaleza, CE, 2010. Disponível em: <http://www.repositorio.ufc.br/ri/bitstr eam/riufc/2806/1/2010_DIS_ALMOREIRA.pdf>. Acesso em: 25 abr. 2020.

SUASSUNA, Ariano. A arte popular no Brasil. Rio de Janeiro: Revista Brasileira de Cultura, 1969 n $^{\circ} 2$, p. 37-43.

. O rico avarento. In: Seleta em prosa e verso. Rio de Janeiro: José Olympio Ed., 1954. p. 5- 16.

. A onça castanha e a ilha Brasil: uma reflexão sobre a cultura brasileira. 1976. $200 \mathrm{f}$. Tese (Livre docência) - Centro de Filosofia e Ciências Humanas, Universidade Federal de Pernambuco, Recife, 1976.

Recebido em: 01/05/2020.

Aprovado em: 25/05/2020. 